\title{
Environmental assay on the effect of poultry manure application on soil organisms in agroecosystems
}

\author{
M. Delgado ${ }^{\text {a, } *}$, C. Rodríguez ${ }^{a}$, J.V. Martín ${ }^{\text {a }}$, R. Miralles de Imperial ${ }^{a}$, F. Alonso ${ }^{b}$ \\ ${ }^{a}$ Environmental Department, INIA, Ctra. La Coruña Km 7. Madrid 28040, Spain \\ ${ }^{\mathrm{b}}$ Agricultural and livestock facilities and environment. EUTT Agrícola. Universidad Politécnica de Madrid. Ciudad Universitaria 28040 Madrid, Spain
}

Keywords:

Poultry manure

Multi-Species Soil System

Enzymatic activities

\begin{abstract}
A B S T R A C T
This paper reports the effects produced on the organisms of the soil (plants, invertebrates and microorganisms), after the application of two types of poultry manure (sawdust and straw bed) on an agricultural land. The test was made using a terrestrial microcosm, Multi-Species Soil System (MS3) developed in INIA. There was no difference in the germination for any of the three species of plants considered in the study. The biomass was increased in the wheat (Triticum aestivum) coming from ground treated with both kinds of poultry manure. Oilseed rape (Brasica rapa) was not affected and regarding vetch (Vicia sativa) only straw poultry manure showed significant difference. For length only Vicia sativa was affected showing a reduction when straw was exposed to poultry manure. When the effect on invertebrates was studied, we observed a reduction in the number of worms during the test, especially from the ground control (13.7\%), higher than in the ground with sawdust poultry manure $(6.7 \%)$, whereas in the ground with straw poultry manure, there was no reduction. The biomass was affected and at the end of the test it was observed that while the reduction of worms in the ground control was about $48 \%$, the number of those that were in the ground with sawdust poultry manure or straw poultry manure decreased by $41 \%$ and $22 \%$ respectively. Finally, the effects on microorganisms showed that the enzymatic activities: dehydrogenase (DH) and phosphatase and basal respiration rate increased at the beginning of the test, and the differences were statistically significant compared with the values of the control group. During the test, all these parameters decreased (except DH activities) but they were always higher than in the ground control. This is why it is possible to deduce that the contribution of poultry manure caused an improvement in the conditions of fertilization and also for the soil.
\end{abstract}

\section{Introduction}

Animal manures have been used effectively as fertilizers for centuries. Poultry manure has long been recognized as the most desirable of these natural fertilizers because of its high nitrogen content. In addition, manures supply other essential plant nutrients and serve as a soil amendment by adding organic matter (Cooperband et al., 2002).

Waste by-products such as excreta or material that are generated by the worldwide annual production of more than 40 million MT of poultry meat and 600 billion eggs are generally land applied as the final step of a producer's waste management strategy. Land application has a great incentive because of its use as fertilizer, improving fertility by adding nutrients $(\mathrm{N}, \mathrm{P}, \mathrm{Na}, \mathrm{K})$ or recovering the structure of the soil by incorporating organic material; however the presence of potentially toxic chemicals (metals and organic chemicals such as pharmaceuticals, endocrine disruptors, detergents, flame retardants or pesticides) involves a potential risk, which may affect soil organisms or plants and the proper soil structure (Sloan et al., 2003).

Animal organisms, microflora and plants are directly exposed to contaminants in poultry manure-amended soil. Contaminant uptake by plants takes place mostly through the soil water phase. Invertebrates can both ingest soil particles and take up dissolved contaminants from the pore water as well. Soil microcosms constitute a proper experimental tool for studying the fate and effects of contaminants under conditions that resemble the natural environment.

Soil microcosms have been reported to be useful tools for assessing effects of chemicals in several species under realistic exposure scenarios (Weyers et al., 2004).

At the Laboratory for Ecotoxicology of INIA, a set of soil microcosms (multi-species soil systems MS3) has been developed in recent years. These systems consist of columns of natural sieved soil assembling soil macro-organisms (plants and invertebrates) providing a complex microbial community, and are particularly suitable for covering arable soils (Van den Brink et al., 2005). Recent studies confirm the ability of these systems to produce relevant information on environmental fate, behavior and effects of chemicals reaching arable soils such as veterinary medicines (Boleas et al., 2005; Fernandez et al., 2004). 
The MS3 has also proved to be functional for assessing effects of combined pollutants in contaminated sites (Fernandez et al., 2005) as well as for monitoring the mobility of metals in relation to biota (Alonso et al., 2006).

An innovative design of soil microcosm, multi-species-soil-system (MS3), has been developed by the INIA's Laboratory to study the effects of the application of two types of poultry manure (sawdust and straw bed) on soil organisms.

\section{Materials and methods}

\subsection{Multi-species-soil-system}

The MS3 is an artificial assemblage of soil macro-organisms lying on homogeneous columns of sieved natural soil (Fernandez et al., 2004; Boleas et al., 2005) that allows the assessment of its effects. In this experiment PVC cylinders $(20 \mathrm{~cm}$ internal diameter and $30 \mathrm{~cm}$ high) covered by a fine nylon mesh at the bottom to avoid soil loss were used. The columns were installed in a climate room with a light-dark cycle of $16-8 \mathrm{~h}(1200 \mathrm{lux} \pm 13 \% \mathrm{CV})$, air conditioning $\left(21 \pm 1^{\circ} \mathrm{C}\right)$ and 55-60\% humidity. The MS3 columns were saturated with spring water. After that, 30 plant seeds and 10 invertebrates were introduced. During the exposure period, the MS3 was irrigated to simulate $1000 \mathrm{~mm}$ rainfall/year.

\subsection{Soil, poultry manure and organisms}

The soil used in this study was collected from an abandoned soil at "La Canaleja", experimental plant that belongs to the INIA, ( $35 \mathrm{~km}$ east of the city of Madrid) and was classified as a Typic Haploxeralf Calciorthid according to soil taxonomy criteria (Soil Survey Staff, 2003). The physico-chemical characteristics of the soil are shown in Table 1. A soil sample $(0-30 \mathrm{~cm})$ was air-dried, passed through a $2 \mathrm{~mm}$ sieve and analyzed by standard soil test laboratory procedures at the Spanish Ministry of Agriculture, Fishing and Food (MAPA, 1994).

Poultry manure was supplied by Castilla León farms located in the northeast of Spain. Table 2 shows the main physicochemical characteristics of the poultry manure mixed with straw or sawdust, which parameters were determined by Standard Methods (APHA, AWWA, and WPCF, 2005). The terrestrial organisms used in the MS3 were invertebrates and terrestrial plants. Eisenia foetida (maintained in culture for several generations in our laboratory) was chosen because it plays a key role in the maintenance of soil structure and in the

Table 1

Physicochemical characterization of the control soil.

\begin{tabular}{|c|c|}
\hline \multicolumn{2}{|l|}{ Parameter } \\
\hline Moisture (\%) & $0.5 \pm 0.04$ \\
\hline $\mathrm{pH}$ & $8.3 \pm 0.45$ \\
\hline $\mathrm{EC}\left(\mathrm{dSm}^{-1}\right)$ & $0.21 \pm 0.02$ \\
\hline Kjeldahl Nitrogen (\%) & $0.13 \pm 5.8$ \\
\hline $\mathrm{NH}_{4}^{+}-\mathrm{N}\left(\mathrm{mg} \mathrm{kg}^{-1}\right)$ & $3.1 \pm 1.8$ \\
\hline $\mathrm{NO}_{3}^{-}-\mathrm{N}\left(\mathrm{mg} \mathrm{kg}^{-1}\right)$ & $17 \pm 4.3$ \\
\hline Organic matter $(\%)$ & $1.7 \pm 0.13$ \\
\hline Extractable $\mathrm{P}$ (mg $\mathrm{kg}^{-1}$ ) & $15 \pm 4.6$ \\
\hline Extractable $\mathrm{K}$ ( $\mathrm{mg} \mathrm{kg}^{-1}$ ) & $176 \pm 5.8$ \\
\hline $\mathrm{Mg}\left(\mathrm{mg} \mathrm{kg}^{-1}\right)$ & $168 \pm 6.4$ \\
\hline $\mathrm{CaCO}_{3}$ equiv. (\%) & $7.5 \pm 2.05$ \\
\hline $\mathrm{Ca}\left(\mathrm{mg} \mathrm{kg}{ }^{-1}\right)$ & $4058 \pm 2.5$ \\
\hline $\mathrm{Na}\left(\mathrm{mg} \mathrm{kg}^{-1}\right)$ & $50 \pm 15.8$ \\
\hline Sand-0.05 mm <D <2 mm (\%) & 77.8 \\
\hline Silt $-0.02 \mathrm{~mm}<\mathrm{D}<0.05 \mathrm{~mm}(\%)$ & 8.7 \\
\hline Silt $-0.002 \mathrm{~mm}<\mathrm{D}<0.02 \mathrm{~mm}(\%)$ & 5.1 \\
\hline Clay-D $<0.002 \mathrm{~mm}(\%)$ & 8.4 \\
\hline Soil type (USDA) & Loamy sand \\
\hline CEC (meq/100 g) & $5.1 \pm 1.8$ \\
\hline
\end{tabular}

EC electrical conductivity, CEC cation exchange capacity.
Table 2

Physicochemical characterization of the poultry manures used in this study (mean \pm standard deviation).

\begin{tabular}{|c|c|c|}
\hline Parameter & Sawdust poultry manure & Straw poultry manure \\
\hline Moisture \% & $26.55 \pm 5.8$ & $24.25 \pm 5.8$ \\
\hline $\mathrm{pH}(1: 5)$ & $8.27 \pm 0.45$ & $7.32 \pm 0.35$ \\
\hline $\mathrm{EC}(1: 10)$ at $25^{\circ} \mathrm{C} \mathrm{dS} \mathrm{m}^{-1}$ & $8.26 \pm 0.67$ & $10.19 \pm 0.67$ \\
\hline TS $(\%)$ & $73.45 \pm 18.9$ & $75.75 \pm 18.9$ \\
\hline FS $(\%)$ & $13.89 \pm 4.3$ & $13.94 \pm 4.3$ \\
\hline VS (\%) & $59.57 \pm 18.3$ & $61.81 \pm 18.3$ \\
\hline Organic matter (\%) & $62.4 \pm 18.3$ & $59.2 \pm 18.5$ \\
\hline Oxidable carbon (\%) & $36.32 \pm 3.02$ & $34.41 \pm 3.04$ \\
\hline Kjeldahl nitrogen (\%) & $3.43 \pm 1.53$ & $4.36 \pm 1.04$ \\
\hline $\mathrm{NH}_{4}^{+}-\mathrm{N}\left(\mathrm{mg} \mathrm{kg}^{-1}\right)$ & $5766 \pm 1.08$ & $8016 \pm 1.71$ \\
\hline $\left.\mathrm{NO}_{3}^{-}-\mathrm{N}(\mathrm{mg} \mathrm{kg})^{-1}\right)$ & $221 \pm 2.30$ & $266 \pm 3.9$ \\
\hline Total P (\%) & $0.974 \pm 0.61$ & $0.956 \pm 0.61$ \\
\hline Total K (\%) & $2.150 \pm 1.27$ & $0.185 \pm 0.14$ \\
\hline Total Ca (\%) & $2.932 \pm 1.27$ & $0.912 \pm 0.61$ \\
\hline Total Mg (\%) & $0.418 \pm 0.04$ & $0.300 \pm 0.04$ \\
\hline Total $\mathrm{Na}(\%)$ & $0.263 \pm 0.13$ & $0.278 \pm 0.13$ \\
\hline Total Al (\%) & $0.097 \pm 0.04$ & $0.091 \pm 0.04$ \\
\hline Total Fe (\%) & $0.076 \pm 0.04$ & $0.075 \pm 0.04$ \\
\hline Total Mn (\%) & $0.043 \pm 0.04$ & $0.298 \pm 0.130$ \\
\hline Total $\mathrm{Zn}\left(\mathrm{mg} \mathrm{kg}^{-1}\right)$ & $196 \pm 6.21$ & $287 \pm 6.27$ \\
\hline Total $\mathrm{Cr}\left(\mathrm{mg} \mathrm{kg} \mathrm{kg}^{-1}\right)$ & $6.37 \pm 2.08$ & $1.50 \pm 0.13$ \\
\hline Total $\mathrm{Cu}\left(\mathrm{mg} \mathrm{kg}^{-1}\right)$ & $109.41 \pm 12.81$ & $31.79 \pm 2.58$ \\
\hline Total Ni (mg kg-1) & $4.50 \pm 0.29$ & $3.21 \pm 0.11$ \\
\hline Total Cd (mg kg-1) & $0.174 \pm 0.023$ & $0.108 \pm 0.013$ \\
\hline Total $\mathrm{Pb}\left(\mathrm{mg} \mathrm{kg}^{-1}\right)$ & $1.054 \pm 0.054$ & $0.42 \pm 0.130$ \\
\hline Total $\mathrm{Hg} 10^{-3}\left(\mathrm{mg} \mathrm{kg}^{-1}\right)$ & $4.42 \pm 0.30$ & $5.28 \pm 2.92$ \\
\hline
\end{tabular}

EC electrical conductivity, TS total solid, FS fixed solid, VS volatile solid.

regulation of soil organic matter dynamics (Lavalle et al., 1997). Certified seeds of the vascular plants Triticum aestivum, Brassica rapa and Vicia sativa were kindly supplied by the Spanish Office of Plant Varieties. The species selected for this study are recommended by the OCDE (OECD, 2004).

\subsection{MS3 experimental protocols}

Poultry manure was applied in two rates: $9 \mathrm{t} \mathrm{ha}^{-1}$ (poultry manure straw) and $10 \mathrm{tha}^{-1}$ (poultry manure sawdust) in an attempt to cover agronomic requirements. Three units of MS3 were used, the first one was filled with $8 \mathrm{~kg}$ of the control soil and the remaining two were filled with poultry manure-amended soil. The treatments and the control were performed in triplicate. The MS3 was saturated (spring water; 730-940 ml/MS3) and after $24 \mathrm{~h}, 10$ adult earthworms (E. foetida) with an average weight of $250-300 \mathrm{mg}$ were placed on top of the soil, 10 wheat seeds (T. aestivum $\mathrm{L}$ ), 10 rape seeds (B. rapa $\mathrm{L}$ ) and 10 vetch seeds $(V$. sativa $L$ ) were introduced into each MS3. After the earthworms were placed on the soil column, the MS3 was irrigated with $100 \mathrm{ml}$ of spring water. Every day, seed germination was observed and MS3 was irrigated (spring water $100 \mathrm{ml}$ ) 5 days a week. At the end of the experimental period (21 days) the MS3 systems were opened, and top soil samples were taken for chemical and ecotoxicological analysis. Enzymatic activities and respiration rate were analyzed on soil samples. Earthworms and plants were removed and counted. The main parameters measured were: percentage of seed germination, above-ground biomass, shoots length for plants and mortality and biomass for earthworms.

\subsection{Ecotoxicological effects}

Effects on plants (seed germination above-ground biomass production and shoot elongation) and earthworms (mortality and biomass) were considered. Moreover, microbial function effects were determined by measuring soil enzymatic activities and respiration rate. Dehydrogenase and phosphatase activities were measured according to Carbonell et al. (2000) and Freeman et al. (1995) respectively. Finally, respiration rate was analyzed according to Fernandez et al. (2004). 


\subsection{Statistical analyses}

Statistical differences for plants, earthworms and soil microorganisms between poultry-manure amended soil treatments and control were assessed by analyzing the variance ( $\mathrm{p} \leq 0.05$ and $\mathrm{p} \leq 0.01)$, oneway ANOVA test and the least significant difference (LSD) multiple range test at $\mathrm{p} \leq 0.05$ and $\mathrm{p} \leq 0.01$ (SAS Institute, 2001).

\section{Results and discussion}

\subsection{Ecotoxicological effects}

\subsubsection{Effects on earthworms}

Mortality was observed in any treatment, but there was reduction of worms during the trial (they escaped from the column) in the control soil (13.7\%) significantly higher than in soil with sawdust poultry manure (6.7\%) and finally, in the soil with straw poultry manure, there was no reduction. Biomass was significantly affected. It was proved that while the reduction of worms in control soil was $48 \%$, in the soil with sawdust or straw poultry manure the reductions were $41 \%$ and $22 \%$ respectively. It can be due to the low availability of food resources in control soil, because the organic matter content was much less than in the amended poultry manure (Van Stralen et al., 2005).

\subsubsection{Effects on plants}

The toxicity data in plants are shown in Table 3. No significant effects were observed in seed germination of $V$. sativa. Significant effects were observed in seed germination of $T$. aestivum and $B$. rapa with a slight decrease in seed germination found in T. aestivum $(\mathrm{p} \leq 0.01$ with sawdust poultry manure). However the largest percentage was observed for $B$. rapa $(\mathrm{p} \leq 0.05$ with sawdust and straw poultry manure). $B$. rapa seems to be the most sensitive species to heavy metal concentration (Carbonell et al. 2009). The fresh biomass was increased in the T. aestivum from soils treated with both kinds of poultry manure. It showed a highly significant difference $(p \leq 0.05)$ for sawdust poultry manure ( $381.9 \mathrm{mg}$ ) and straw poultry manure (363.9 mg).

$B$. rapa and $V$. sativa did not show significant differences, only $V$. sativa with straw poultry manure $(336.4 \mathrm{mg})$ showed a significant difference $(p \leq 0.05)$. In terms of shoot length, only $V$. sativa showed a significant difference $(\mathrm{p} \leq 0.05)$ when it was mixed with straw poultry manure $(40.7 \mathrm{~cm})$.

\subsubsection{Effects on microorganisms}

The enzymatic activities (dehydrogenase, phosphatase) and soil basal respiration rate, the parameter used to monitor microbial activity, increased in poultry manure amended soils. Compared with the values of the control group there were statistical significant differences. During

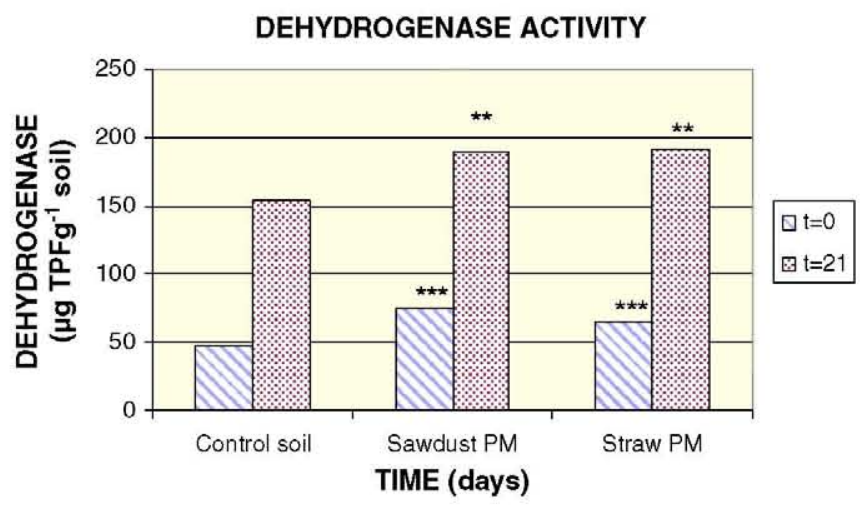

Fig. 1. Dehydrogenase activity of control soil, sawdust poultry manure and straw poultry manure for 0 and 21 days. Statistically significant difference for the application rate in the one way ANOVA test $\left({ }^{* *} \mathrm{p} \leq 0.01\right.$ and $\left.{ }^{* * * *} \mathrm{p} \leq 0.001\right)$.

the test, all these parameters decreased (except DH activities), due to depletion of organic substrates provided by the amendment, which led to a progressive decrease in microbial and enzymatic activities as a result of mineralization processes in soils. The enzyme activity of dehydrogenase showed significant difference $(\mathrm{p} \leq 0.01)$ for sawdust poultry manure (Fig. 1) with $190.36 \mathrm{\mu g} \mathrm{TPFg}^{-1}$ soil, and straw poultry manure (Fig. 2) with $191.55 \mu \mathrm{g} \mathrm{TPFg}^{-1}$ soil, in accordance with Ros et al. 2003. The enzymatic activity phosphatase and soil basal respiration rate, showed significant difference ( $\mathrm{p} \leq 0.001$ ) for both, sawdust poultry manure and straw poultry manure (Figs. 3 and 4). The activity of phosphatase on sawdust and straw poultry manure were $96.93 \mu \mathrm{g} \mathrm{MU} \mathrm{g}{ }^{-1}$ soil, and $110.24 \mu \mathrm{g} \mathrm{MU} \mathrm{g}{ }^{-1}$ soil, respectively. The increase in this activity is fundamentally due to the additional source of organic matter and nutrients which make up the poultry manure and which have a stimulating effect on microbial activity. This led to an increase in phosphatase synthesis (Chen, 2003). Soil basal respiration in sawdust and straw poultry manure was $2.87 \mathrm{mg} \mathrm{CO}_{2} 100 \mathrm{~g}^{-1}$ soil, and $2.65 \mathrm{mg} \mathrm{CO}_{2} 100 \mathrm{~g}^{-1}$ soil, respectively according to Wang et al., 2003.

\section{Conclusion}

The soil microcosm reproduced the specific conditions of agricultural arable land, such as the MS3 system used in this study and it offers a proper alternative for the ecotoxicological testing of these residues.

After applying two types of poultry manure (sawdust or straw bed) on an agricultural land, the effects on soil organisms (plants, invertebrates and microorganisms) were studied and it was possible to affirm

Table 3

Ecotoxicological effects of the poultry manure-amended soil on earthworms and plants (mean \pm standard deviation).

\begin{tabular}{|c|c|c|c|c|c|}
\hline Parameter & Species & Days & Control & Sawdust poultry manure & Straw poultry manure \\
\hline Mortality (\%) & E. foetida & 21 & $13.7 \pm 4.3$ & $6.7 \pm 1.8$ & $0 \pm 0$ \\
\hline Biomass (mg) & E. foetida & 21 & $504.9 \pm 112.8$ & $489.3 \pm 101.3$ & $516.5 \pm 109.9$ \\
\hline Biomass loss (\%) & E. foetida & 21 & $48 \pm 15.8$ & $41 \pm 15.5$ & $22 \pm 8.2$ \\
\hline \multirow[t]{3}{*}{ Seed germination (\%) } & T. aestivum & 21 & $96.7 \pm 15.8$ & $80 \pm 10.0^{*}$ & $93.3 \pm 11.5$ \\
\hline & V. sativa & 21 & $90.0 \pm 17.3$ & $96.7 \pm 15.8$ & $93.3 \pm 11.5$ \\
\hline & B. rapa & 21 & $90.7 \pm 15.3$ & $63.3 \pm 9.8^{*}$ & $80.0 \pm 10.0^{*}$ \\
\hline \multirow[t]{3}{*}{ Shoot length $(\mathrm{cm})$} & T. aestivum & 21 & $29.5 \pm 2.8$ & $30.2 \pm 5.8$ & $30.0 \pm 2.3$ \\
\hline & V. sativa & 21 & $44.5 \pm 5.4$ & $43.0 \pm 4.3$ & $40.7 \pm 3.9^{*}$ \\
\hline & B. rapa & 21 & $14.5 \pm 2.8$ & $11.4 \pm 3.0$ & $12.1 \pm 2.9$ \\
\hline \multirow[t]{3}{*}{ Shoot biomass $(\mathrm{mg})^{\mathrm{a}}$} & T. aestivum & 21 & $297.9 \pm 65.1$ & $381.9 \pm 67.9^{*}$ & $363.9 \pm 70.8^{*}$ \\
\hline & V. sativa & 21 & $390.7 \pm 65.1$ & $378.2 \pm 65.5$ & $336.4 \pm 53.8^{*}$ \\
\hline & B. rapa & 21 & $179.7 \pm 10.3$ & $216.9 \pm 11.4$ & $193.4 \pm 12.7$ \\
\hline
\end{tabular}

\footnotetext{
a Fresh biomass/plant

* $\mathrm{p} \leq 0.05$.
} 


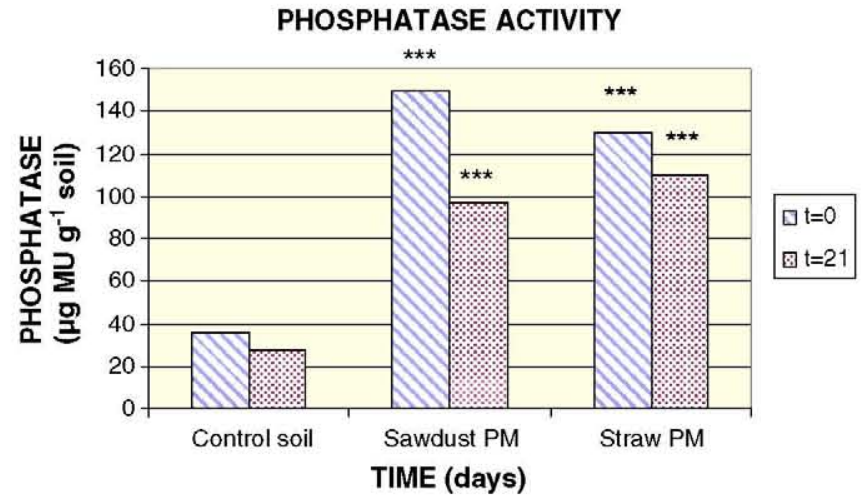

Fig. 2. Phosphatase activity ( $\mu \mathrm{g} M \mathrm{MU}^{-1}$ soil) of control soil, sawdust poultry manure and straw poultry manure for 0 and 21 days. Statistically significant difference for the application rate in the one way ANOVA test $\left({ }^{* * *} \mathrm{p}<0.001\right)$.

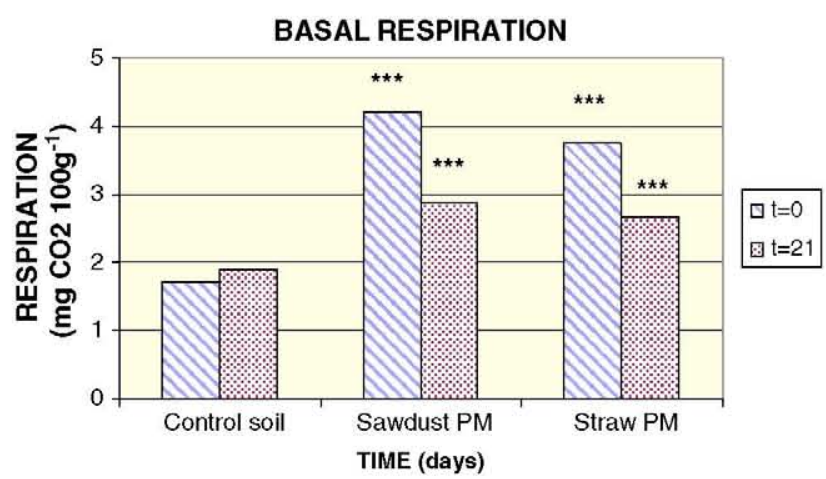

Fig. 3. Basal respiration ( $\mathrm{mg} \mathrm{CO} \mathrm{CO}_{2} 100 \mathrm{~g}^{-1}$ soil) of control soil, sawdust poultry manure and straw poultry manure for 0 and 21 days. Statistically significant difference for the application rate in the one way ANOVA test $\left({ }^{* * *} \mathrm{p}<0.001\right)$.

that the contribution of poultry manure was an improvement not only for the conditions of fertilization due to additional source of organic water and nutrients but also for the soil microorganisms which had a stimulating effect on microbial activity.

\section{Acknowledgments}

We are grateful to INIA-FEDER for funding this study as part of the RTA2005-00120-CO2-01 and RTA2009-00074-00-00 projects. The authors wish to extend their sincere thanks to Ecotoxicology Laboratory for technical assistance.

\section{References}

Alonso E, Fernandez C, Pro J. Carbonell G, Tarazona JV, Carbonell G. Assessing the influence of biota on metal mobility in multi-species soil system. Soil Sediment Contam 2006; 15:327-37.

APHA AWWA WPCF. Standard Methods for the Examination of Water and Wastewater. 21st ed. Washington: American Public Health Association, American Water Works Assotiation and Water Environment Federation; 2005 [874 p.].

Boleas S, Alonso C, Pro J, Babín MM, Fernandez C, Carbonell G, Tarazona JV. Effects of sulfachlorpyridazine in MS3-arable land: a multi-species soil system for assessing the environmental fate and effects of veterinary medicines. Environ Toxicol Chem 2005;24:811-9.

Carbonell G, Pablos MV, García P, Ramos C, Sánchez P, Fernández C, Tarazona JV. Rapid and cost-effective multiparameter toxicity tests for soils microorganisms. Sci Total Environ 2000;247:143-50.

Carbonell G, Pro J, Babin MM, Fernández C, Alonso E, Tarazona JV. Sewage sludge applied to agricultural soil: ecotoxicological effects on representative soil organisms. Ecotoxicol Environ Saf 2009;72:1309-19.

Chen $H$. Phosphatase activity and P fractions soils of an 18-year old Chinese fir (Cunninghamia lanceolata) plantation. Forest Ecol Manage 2003;178:301-10.

Cooperband L, Bollero G, Coale F. Effect of poultry litter and compost on soil nitrogen and phosphorus availability and com production. Nutr Cycl Agroecosyst 2002;62: 185-92.

Fernandez C, Alonso C, Babín MM, Pro J, Carbonell G, Tarazona JV. Ecotoxicological assessment of doxicyclyne in aged pig manure using multispecies soil system. Sci Total Environ 2004;323:63-9.

Fernandez C, Cagigal E, Veja MM, Tarazona JV. Ecological risk assessment of contaminated soils through direct toxicity assessment. Ecotoxicol Environ Saf 2005;62: 174-84.

Freeman C, Liska G, Ostle NJ, Jones SE, Lock MA. The use of fluorogenic substrates for measuring enzyme activity in peatlands. Plant Soil 1995;175:113-4.

Institute SAS. SAS User's Guide: Statistic. Cary, NC: SAS inst.; 2001.

Lavalle P, Bignell D, Lepage M, Wolters V, Roger P, Inenson P, Heal OW, Dhillion S. Soil function in a changing world: the role of invertebrate ecosystem engineers. Eur J Soil Biol 1997:33:159-93.

MAPA. Official Spanish Methods of Analyses. 3th ed. MAPA, Madrid, Spain; 1994.

$O E C D$. (Organization for Economic Cooperation and Development) OCDE guidelines for testing of chemicals. Soil microorganisms: nitrogen transformation test. OECD Guideline No 216, Paris, France; 2004.

Ros M, Hernandez MT, Garcia C. Soil microbial activity after restoration of a semiarid soil by organic amendments. Soil Biol Biochem 2003;35:463-9.

Sloan DR, Kidder G, Jacobs RD. Poultry manure as a fertilizer. PS1 IFAS Extension. University of Florida; 2003 [241 p.].

Soil Survey Staff. Keys to soil taxonomy. Natural Resources Conservation Service 9th ed. Washington: USDA; 2003.

Van den Brink P, Tarazona JV, Solomon K, Hollgland I. The use of terrestial and aquatic microcosmos and mesocosms for the ecological risk assesment of veterinary medical produts. Environ Toxicol Chem 2005;24:820-9.

Van Stralen NM, Donker MH, Vijver MG, Van Gestel CAM. Bioavailability of contaminants estimated from uptake rates into soil invertebrates. Environ Pollut 2005; 136:409-17.

Wang W], Dalal RC, Moody OW, Smith CJ. Relationships of soil respiration to microbial biomass, substrate availability and clay content. Soil Biol Chem 2003;35:273-84.

Weyers B, Skull-Kluttgen B, Knaker T, Martin S, Van Gestel C. Use of terrrestial model ecosystem data in environmental risk assesment for industrial chemicals. Biocides Plant Prot Prod EU Ecotoxicol 2004:13:163-76. 